\title{
Selective Granulocyte and Monocyte Apheresis as a Non-Pharmacological Option for Patients with Inflammatory Bowel Disease
}

\author{
Gerda C. Leitner ${ }^{a}$ Nina Worel ${ }^{a}$ Harald Vogelsang ${ }^{b}$ \\ a University Clinic for Blood Group Serology and Transfusion Medicine, \\ ${ }^{\mathrm{b}}$ University Clinic of Gastroenterology, 3rd Internal Medicine, Medical University of Vienna, Vienna, Austria
}

\section{Keywords}

Adacolumn ${ }^{\circledast}$. Cellsorba ${ }^{\circledR}$. Selective granulocyte and monocyte cell adsorption - Inflammatory bowel disease

\section{Summary}

Ulcerative colitis and Crohn's disease are the two most prevalent inflammatory bowel diseases. In both cases, the medically refractory and steroid-dependent type presents a therapeutic challenge. To help resolve this problem, a mainly Japanese team developed a new therapeutic option. There are two systems, both of which are able to selectively remove the main mediators of the disease, namely the activated pro-inflammatory cytokine-producing granulocytes and monocytes/macrophages, from the patient's blood circulation $(\mathrm{GMA}=$ granulocyte monocyte apheresis). One of the two systems is the Adacolumn $^{\circledast}$ (Immunoresearch Laboratories, Takasaki, Japan) consisting of the ADA-monitor and a single-use column, which contains approximately 35,000 cellulose acetate beads. The exact mode of action is not yet sufficiently understood, but however, a modulation of the immune system takes place. As a result, less pro-inflammatory cytokines are released. Furthermore, the production of anti-inflammatory interleukin-1 receptor antagonist is increased, and the apoptosis of granulocytes boosted. The decreased LECAM-1-expression on leukocytes impedes the leukotaxis to the inflamed tissue, and CD10-negative immature granulocytes appear in the peripheral blood. Another effect to be mentioned is the removal of the peripheral dendritic cells and the leachate of regulatory $T$ cells (T-regs). The second system is the Cellsorba ${ }^{\circledR}$ FX Filter (Asahi Medical, Tokyo, Japan). The range of efficiency, the indication, and the procedure are very similar to the Adacolumn. Solely the additional removal of lymphocytes can possibly limit the implementation since lymphopenia can increase the risk of autoimmune disease. Both systems provide a low-risk therapy with few adverse reactions. ASFA recommendations for GMA in inflammatory bowel disease are $2 \mathrm{~B}$ due to the fact that not enough randomized double-blind studies are available to proof the efficacy of this treatment.

\section{KARGER}

Fax +497614520714

Information@Karger.de

www.karger.com (c) 2012 S. Karger GmbH, Freiburs

$1660-3796 / 12 / 0394-0246 \$ 38.00 / 0$

Accessible online at:

www.karger.com/tm
Schlüsselwörter

Adacolumn $^{\circledast}$. Cellsorba ${ }^{\circledR}$. Selektive Granulozyten- und Monozyten-Apherese · Entzündliche Darmerkrankungen

\section{Zusammenfassung}

Die beiden häufigsten Vertreter von entzündlichen Darmerkrankungen sind Colitis ulcerosa und Morbus Crohn. In beiden Fällen stellen die therapieresistenten bzw. steroidabhängigen Formen eine therapeutische Herausforderung dar. In diesem Sinne wurde eine nichtpharmakologische Therapieoption entwickelt. Es gibt zwei Systeme, die beide dazu dienen den Hauptmediator der Erkrankung, nämlich Granulozyten, die aktivierte proinflammatorische Zytokine produzieren, und Monzoyten/Makrophagen selektiv aus dem Blutkreislauf des Patienten zu entfernen (GMA = granulozytäre monozytäre Apherese). Ein System ist die Adacolumn ${ }^{\circledR}$ (Immunoresearch Labaratories, Takasaki, Japan) bestehend aus dem ADA-Monitor, und einer Einmal-Säule, die zirka 35000 Zellulose-Azetat-Kügelchen enthält. Der genaue Wirkmechanismus ist im Detail noch nicht geklärt. Jedenfalls wird eine Modulation des Immunsystems erreicht, wodurch weniger proinflammatorische Zytokine freigesetzt werden. Andererseits wird verstärkt der antiinflammatorisch wirkende Interleukin-1-Rezeptor-Antagonist gebildet und die Apoptose von Granulozyten forciert. Die verminderte LECAM-1-Expression auf Leukozyten hemmt die Leukozytenmigration zum entzündeten Gewebe, und unreife, CD10-negative Granulozyten erscheinen im peripheren Blut. Eine nicht unwesentliche Wirkung wird auch der Entfernung von peripheren dendritischen Zellen und der Ausschwemmung von sogenannten regulatorischen T-Zellen (T-regs) zugeschrieben. Das 2. System ist der Cellsorba ${ }^{\circledR}$ FX Filter (Asahi Medical, Tokyo, Japan). Das Wirkungsspektrum, die Indikationen sowie die Durchführung sind sehr ähnlich der Adacolumn ${ }^{\circledast}$. Lediglich die zusätzliche Entfernung von Lymphozyten kann unter Umständen zu einer Einschränkung in der Anwendung führen, da Lymphopenien bekannterweise Autoimmunerkrankungen fördern können. Beide Therapieformen gelten als risiko- und nebenwirkungsarm. Aufgrund des Fehlens von einer ausreichenden Anzahl an randomisierten Doppelblindstudien und Langzeitbeobachtungen wird in den ASFA-Richtlinien nur eine Therapieempfehlung 2B ausgesprochen. 


\section{Introduction}

To understand a disease as an imbalance of inner harmony is as old as medicine itself. Already medicine men and healers of the Neolithic tried to separate (apherein = to separate, Greek)' the good' from 'the bad' [1,2].

Blood letting (phlebotomy) was the therapeutic option centuries ago to remove the cause of disease. Today, this rather crude technique is replaced by the apheresis technique. Nowadays the removal of pathogens or disease-modulating agents (i.e. activated leukocytes) is done by either a complete depletion like plasma exchange therapy (TPE) or by the selective removal of immunoglobulins (immunoadsorption) or target cells (selective cell apheresis, cytapheresis) [1]. Selective leukocyte apheresis was developed for the selective removal of activated leukocytes, predominately granulocytes and monocytes or macrophages from the patients' circulation (granulocyte monocyte apheresis = GMA) Especially in inflammatory bowel disease (IBD), namely ulcerative colitis (UC) and Crohn's disease (CD), the severity of the disease and mucosal damage correlates with the excess of mucosal granulocyte infiltration [3-5]. Activated granulocytes are the main source of pro-inflammatory cytokines enhancing and perpetuating inflammation and increasing shelf life of the leukocytes itself which induces a circulus vitiosus [6-9]. In the end of the 1989s, lympho-plasma apheresis was an established method in the treatment of IBD. It was replaced by the selective removal of $\mathrm{T}$ lymphocytes. The mode of action was unclear but this treatment promised to be a therapeutic option for patients with UC and CD [10]. In both entities patients require long-time drug treatment and are exposed to potentially severe side effects due to the therapy with steroids or monoclonal antibodies [11-13]. Additionally, steroid refractoriness or steroid dependence as well as the threat of surgery led to the investigation of further nonpharmacological treatment options which selectively remove leukocytes - the main source of inducing and maintaining intestinal inflammation [14, 15]. Thus, two types of leukocyte removal systems for GMA were developed: the adsorptive carrier-based Adacolumn ${ }^{\circledR}$ system (Immunoresearch Laboratories, Takasaki, Japan) and a removal filter column, the Cellsorba ${ }^{\circledR}$ FX (Asahi Medical, Tokyo, Japan). In this paper we focused mainly on Adacolumn treatment due to the fact that the Adacolumn treatment is more frequent in European countries than the Cellsorba therapy and both have exactly the same domain. Both systems have been compared in a prospective clinical trial that demonstrated equivalent response in patients with moderate-to-severe active UC [16] (ASFA guidelines).

\section{Device and Methods}

Both systems described in the following are self-contained devices. A combination with the active column (filter) and a conventional cell separator is currently not possible.

\section{Adacolumn}

The ADA system $(\mathrm{A}=$ adsorption, $\mathrm{D}=$ distribution and $\mathrm{A}=$ apheresis), consisting of the ADA-monitor, a tubing set and a column (fig. 1), has been developed for selective adsorption of granulocytes and monocytes/macrophages (GMA). It is approved by the Japanese Ministry of Health and Welfare and is CE marked in Japan and Europe by the TUV since 1999 [17, 18]. Adacolumn is a whole-blood type cytapheresis system. The adsorption mechanism is based on a column, filled with about 35,000 cellulose acetate beads (G-1 beads) (fig. 1). Heparin-anticoagulated whole blood passes the column where the adsorption of activated leukocytes (granulocytes and monocytes/macrophages) proceeds. Leukocyte-depleted

Fig. 1. Adacolumn and Ada-monitor. The column contains about 35,000 cellulose acetate beads in $0.9 \%$ saline solution.

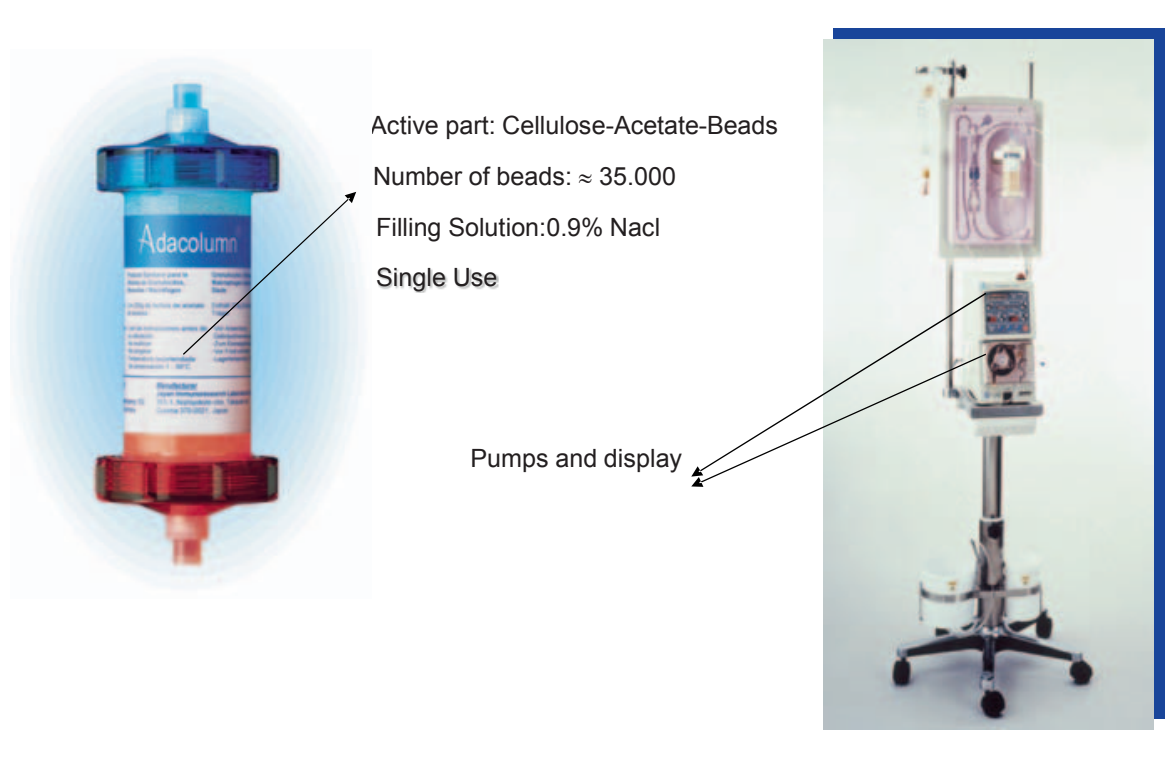




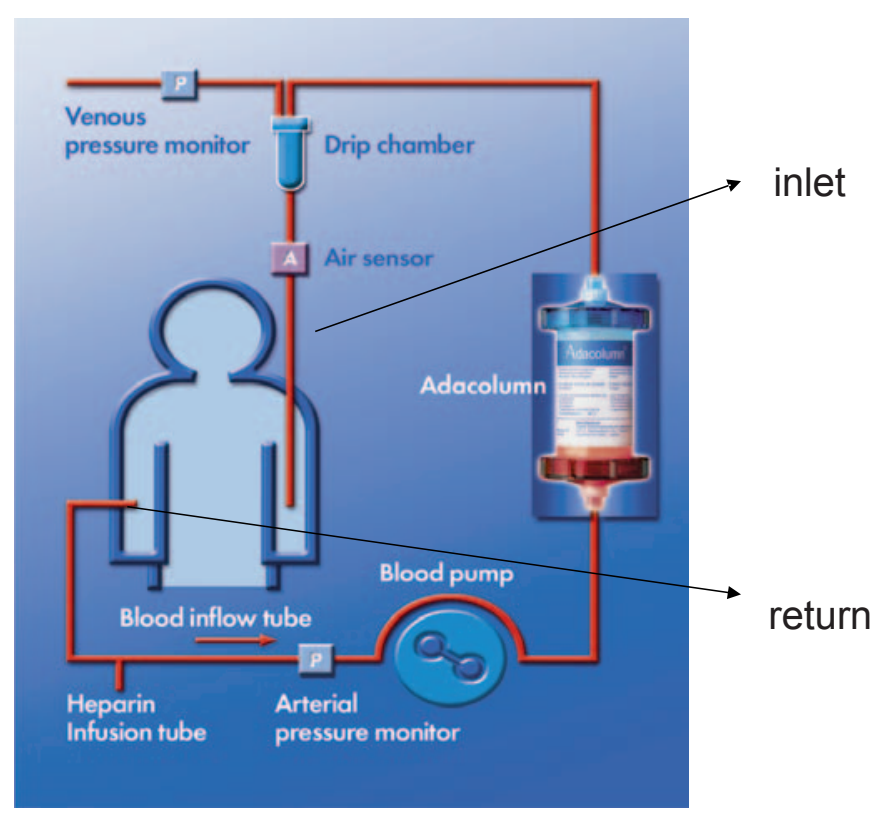

Fig. 2. During selective leukocyte adsorption (GMA) whole blood is drawn from the patient through the column which contains the G-1 beads. Granulocytes and monocytes/macrophages are absorbed selectively and the so treated whole blood is re-infused to the patient through a contralateral vein.

whole blood is re-infused to the patient through a contralateral vein (fig. 1,2). The standard treatment covers 5 sessions within 5 weeks with a frequency of 1 session per week. In each session $1,800 \mathrm{ml}$ of the patients' whole blood should be treated with an optimal flow rate of $60 \mathrm{ml} / \mathrm{h}$. The ' 1 -week' interval was chosen because the treatment-associated effects are measurable at least for about 1 week.

\section{Current Knowledge about the Mode of Action}

The mode of action is not fully understood yet. A selective adsorption of granulocytes and monocytes/macrophages is mediated through a fragment crystallizable gamma (Fcy) and complement receptor binding to the cellulose acetate beads. Approximately $65 \%$ of granulocytes and $55 \%$ of monocytes are selectively absorbed in the column and thus depleted from the streaming blood $[19,20]$. However, the number of granulocytes and monocytes in the patient's circulation does not drop under reference (normal) values, as a rapid mobilization of naïve (CD10-negative) leukocytes occurs [21]. Therefore, Adacolumn induces no quantitative change in white blood cell (WBC) counts but has a more qualitative effect on peripheral blood counts. CD10 is predominately expressed on precursor cells of the lymphocyte lineage but is also found at a low level on mature neutrophils [22].

Ramlow et al. [23] showed marked phenotypic changes in granulocytes during Adacolumn treatment, i.e. significant in down-regulation of L-selectin (CD62L) expression of granulocytes while Mac-1 (CD11b) was up-regulated [19, 20, 24]. L-selectin mediates the migration of activated leukocytes into inflamed tissues. Down-regulation of L-selectin combined with up-regulation of Mac-1 led to marked decrease in the adhesive capacity of leukocytes to the inflamed tissues [18, 23]. The role of L-selectin in inflammation is well known and a target for anti-inflammatory therapy [25].

Waitz et al. [26] identified a significantly lower number of dendritic cells after the Adacolumn treatment, which may also contribute to the efficacy of this therapy. Further, the Adacolumn system is known to induce an immunomodulation due to adsorption of cytokine-producing monocytes, mainly the pro-inflammatory CD14+ CD16+ DR++ subset. This monocyte subpopulation can promote and perpetuate inflammatory conditions by producing large amounts of pro-inflammatory cytokines including TNF- $\alpha$ and IL-1 $\beta$ [20, 23, 24]. The adsorption of this elevated pro-inflammatory phenotype was found to result in a dramatic decrease of TNF- $\alpha$ and IL-1 $\beta$ levels $[18-20,23,24]$ which also leads to apoptosis of activated leukocytes. As mentioned above, activated leukocytes are known to have an increased life span and therefore an inflammation-prolonging effect [6]. Not only the decrease of proinflammatory cytokines (IL-1ra, IL-6, IL-8) but also the increase of anti-inflammatory cytokines was shown to contribute to the therapeutic effect of Adacolumn treatment $[6,18$, $20,23,24]$. As already reported, the anti-inflammatory cytokine release into the patients' circulation is caused by leukocyte adhesion to the G-1 beads [18, 20, 21, 23, 24] .

An effect which is generally observed in the extracorporeal treatment setting is the rise in CD4+ CD25+ regulatory T cells (T-regs) $[27,28]$. This phenomenon is also seen in patients undergoing extracorporeal photopheresis treatment (ECP) [29, 30]. The naturally occurring $T$ cells are known to play an important role in controlling the immune function in the digestive tract as well [28]. They have a great potential in the prevention of excessive immune reactions. The efficacy of Adacolumn treatment in AIDS is inter alia ascribed to this phenomenon (rise of CD4+ T cells) [24, 31].

\section{Side Effects}

The Adacolumn treatment has an excellent safety profile. Reported side effects were mild, and until now no procedure had to be discontinued due to adverse events. Typical adverse reactions were dizziness, nausea, headache, flushing, and fever [32].

\section{Anticoagulation}

According to the manufacturer's recommendations, the system requires unfractionated heparins (UFH) or nafamostate mesilate (a synthetic serine protease inhibitor, which is commonly used in Japan) as anticoagulation [33]. UFH bears the risk to induce heparin-induced thrombocytopenia type II (HIT II); thus the peripheral platelet counts has to be monitored carefully [34] during the treatment. In case of developing HIT II the treatment has to be stopped or switched to the Cellsorba system which allows ACD-A as anticoagulation medium 

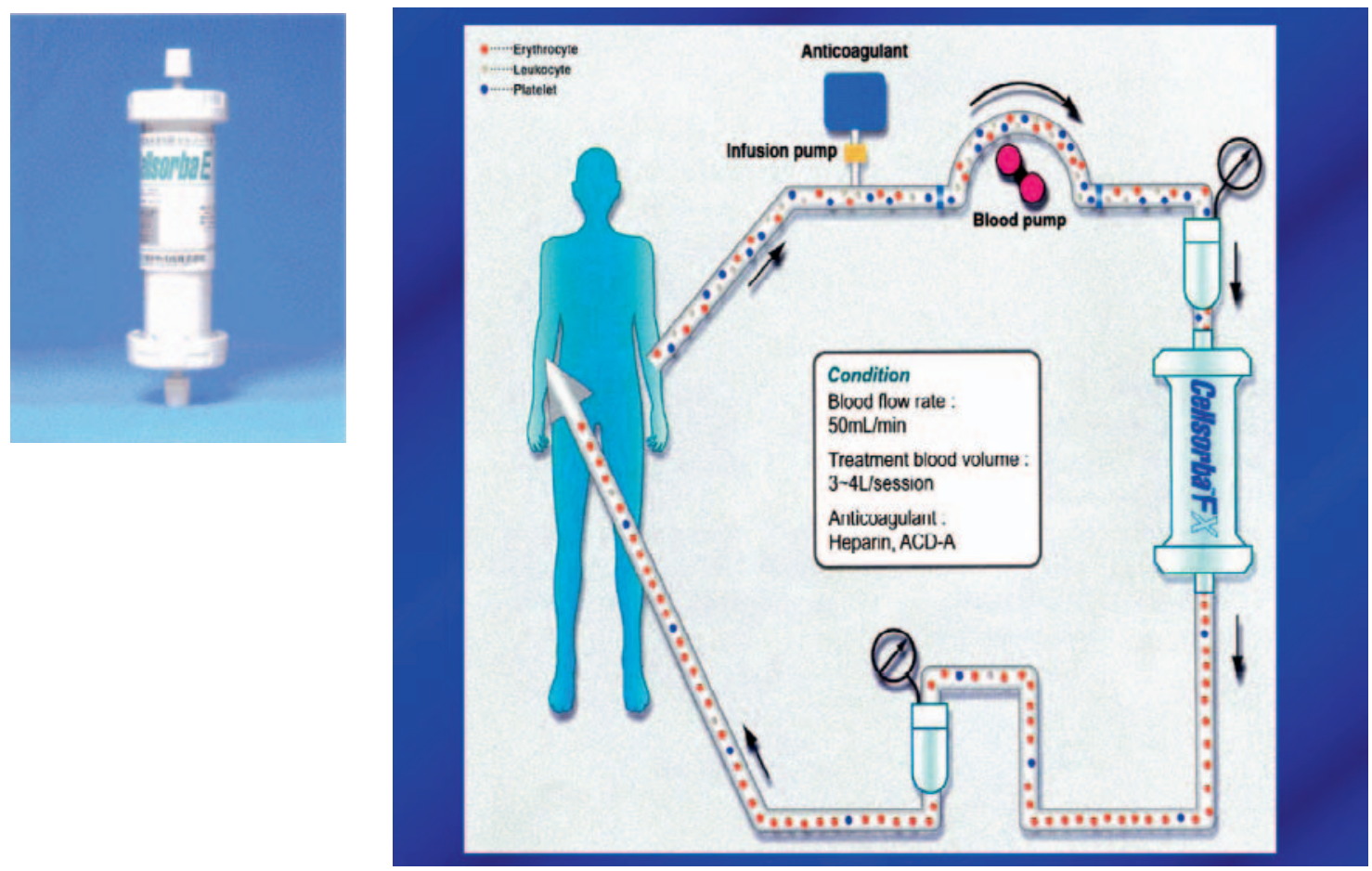

Fig. 3. Cellsorba system (pumps, tubing set, and filter)

(fig. 3). There is one report which describes the successful use of nafamostate mesilate combined with aspirin in a patient with HIT II undergoing hemodialysis [35], but no such recommendations for the Adacolumn treatment are available.

\section{Cellsorba}

The Cellsorba system is also a whole-blood type cytapheresis and is used for the same indications as Adacolumn. It is approved by the Japanese Ministry of Health and Welfare since 1989 [36]. The main difference is the build-up of the column [36]. It consists of 2 non-woven fabric filters (polyester fibers). The main internal filter is surrounded by an outer pre-filter. Leukocytes are removed from the patients' circulation by either filtration (pre-filter) or adhesion to the filter (inside filter) [5]. Leukocyte removal apheresis depletes granulocytes, monocytes, lymphocytes, and platelets which are also known to have a pro-inflammatory effect [37, 38], alters cell population profiles, modulates cytokine production, and induces a spill-over of immature bone marrow-derived cells. In general, the safety profile complies with Adacolumn but, although the lymphocyte depletion is moderate, transient lymphopenias were observed. This might be a limiting factor for the Cellsorba system as lymphopenia can promote autoimmune diseases [39-41]. Genetic, environmental, and autoimmune origins in IBD are still being discussed [42]. Although the majority of clinical studies enrolled only small numbers of patients and had open-labeled designs, leukocytapheresis showed clinical efficacy with an excellent safety profile $[43,44]$.

\section{Clinical Effectiveness}

The severity of the disease is classified for UC by a Clinical Activity Index (CAI), Rachmilewitz index, or Mayo score including stool frequency, rectal bleeding, the endoscopic activity of the colon, and a physician rating of disease activity. Each of these items is given a number from 0 to 3, with 3 being the highest rating for disease activity. Additionally laboratory findings (e.g. peripheral hemoglobin values, leukocyte counts, sedimentation rate, and CRP values) are recorded [45]. A drop to less than 2 points is defined as a clinically relevant remission. The Crohn's Disease Activity Index(CDAI) is a research tool used to quantify the symptoms of patients with $\mathrm{CD}$. CDAI is used in order to define response or remission of disease. The CDAI was developed by Best and colleagues [46] from the Midwest Regional Health Center in Illinois in 1976. Further, in steroid-dependent or steroid-refractory patients the tapering or discontinuation of steroids is assessed as a clinical response $[19,47]$.

Most clinical trials are conducted using the Adacolumn system in both UC and CD whereby UC is the leading entity. The best responders seem to be steroid-naïve patients followed by steroid-dependent patients or steroid-refractory patients with a short history of disease [19, 32]. In 2005 a doubleblind, sham-controlled trial was initiated to prove the efficacy of GMA in UC in Europe (Adacolumn ${ }^{\circledR}$ Trial 512-04-205). This trial failed to demonstrate the efficacy for induction of clinical remission in patients with moderate-to-severe UC but showed an endoscopic improvement in patients with a Riley score 7 (histologically active inflammation) [17]. Yamamoto et al. [48] also showed that GMA is more effective in patients 
Table 1. Diseases and responsible mode of actions

\begin{tabular}{ll}
\hline Disease & Mode of action \\
\hline UC & $\begin{array}{l}\text { depletion of activated leukocytes, } \\
\text { Immunomodulation } \\
\text { depletion of activated leukocytes, } \\
\text { Immunomodulation } \\
\text { depletion of neutrophils, IgG and complement } \\
\text { RA }\end{array}$ \\
Pyoderma, psoriasis & $\begin{array}{l}\text { downregulation of chemokine receptor CXC3 } \\
\text { CD4+ T cells }\end{array}$ \\
HCV & reduction of virus load \\
Behcet's disease & depletion of neutrophils
\end{tabular}

$\mathrm{RA}=$ rheumatoid arthritis.

with active UC. Clinical remission was observed in 56 of 124 of included patients $(45 \%)$. In 32 of the responding patients additional mucosal healing was achieved, resulting in maintaining clinical remission at a significantly higher rate than in patients without mucosal healing.

In 2011, Zhu et al. [44] confirmed in a meta-analysis the excellent tolerability of GMA and postulated that GMA may be superior in inducing remission and tapering steroid dosage to conventional pharmacotherapy in patients with UC. The same conclusion was drawn in a review from Habermalz and Sauerland [49]. More patients responded to GMA than to an increase in steroid dosage.

The number and frequency of treatments is a recurring issue in this setting. Conventionally 5 sessions (1/week) are performed in the European countries as standard [50]. But also 10 or more treatments are performed in patients with severe UC $[47,50,51]$. , in the 'Sandtrial' 10 sessions within 8 weeks were scheduled [17]. Dignass et al. [50] were able to demonstrate that 5 treatments are not inferior to 10 treatments in terms of clinical remission and tapering of steroid dosage. The shorter treatment regimen is more convenient for patients and staff and less cost-expensive.

Almost all studies are able to show a satisfying short-term outcome accompanied by negligible side effects of GMA but fail to address the long-term outcome.

\section{Other Indications}

The therapeutic value of GMA in autoimmune diseases which are associated with elevated and activated granulocytes, circulating immune complexes, and high levels of pro-inflammatory cytokines are well known $[19,20,43]$. Thus a beneficial effect of GMA was also observed in rheumatoid arthritis [5254]. The field of application has widened to virus-induced immune alterations. AIDS pathogenesis results from immunological response to HIV [31]. GMA was shown to be effective in changing the immunological situation to normal by increasing CD4 helper T cells and reducing virus load [31]. The same

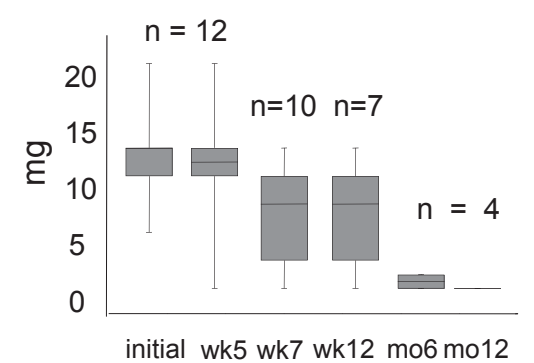

Fig. 4. a Tapering in the dosage of prednisolon. b Course of the CAI during the observation period of 12 months after 5 sessions of GMA in the evaluable patients. All patients were diagnosed with UC. $\mathrm{n}=$ Number of evaluable patients, $\mathrm{wk}=$ week, mo = month .

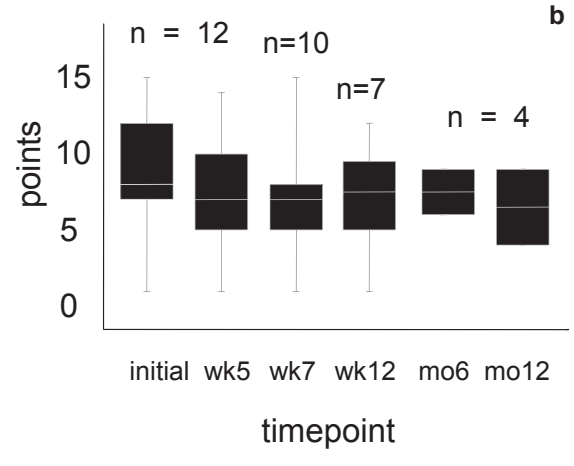

effect (decreasing virus load) was observed in patients with chronic hepatitis $\mathrm{C}[55,56]$.

Diseases which may benefit from GMA and modes of action are listed in table 1.

\section{Single Center Experience}

In a prospective trial, 12 patients ( 2 females, 10 males; median age 49 (range 24-66) years) diagnosed with UC were treated with GMA at our institution. All of them received mesalazine (5-aminosalicylic acid, 5-ASA) and steroids; 3 patients were also given immunosuppressive drugs. The history of disease ranged between 3 and 12 years. The median CAI was 8.5 (range 4-14) points. All patients were treated with Adacolumn in weekly intervals for 5 sessions (patients with $\mathrm{CAI}<8$, $n=7$ ) or for 10 sessions (patients with $\mathrm{CAI} \geq 8, \mathrm{n}=5$ ). In each session $1,800 \mathrm{ml}$ whole blood was processed. Side effects were mild and included cephalgia, dizziness, fatigue, and fever at night. No treatment had to be discontinued, and no intervention due to side effects was necessary. The steroid demand, CAI, CRP, and peripheral blood counts were monitored preapheresis, 2 weeks post apheresis and then monthly during a period of 12 months (fig. 4, table 2). Our aim was to induce clinical remission and tapering of steroids.

Three male patients were excluded from further evaluation. One of them underwent hemicolectomy immediately after the completion of Adacolumn treatment. The second patient was set on CsA 2 weeks after Adacolumn discontinuation, and the 3rd one developed rectum carcinoma 9 months after GMA and was excluded at this time point. A mean drop of 2 CAI points was observed 2 weeks after treatment in the 
Table 2. Single center experience - course of peripheral blood counts (leukocytes and hemoglobin values) ${ }^{\mathrm{a}}$

\begin{tabular}{|c|c|c|c|c|}
\hline & Wk $0(n=12)$ & $\mathrm{Wk}+2(\mathrm{n}=10)$ & Month $4(\mathrm{n}=7)$ & Month $6(n=4)$ \\
\hline WBC $10^{9} / 1$ & $7(5.6-14.6)$ & $7.15(4.8-15.2)$ & $6.8(5.7-12.6)$ & $6.1(6.1-11.5)$ \\
\hline $\mathrm{Hb} \mathrm{g} / \mathrm{dl}^{\mathbf{b}}$ & $12.3(7.4-15.3)$ & $12.5(10.7-15.4)$ & $12.3(11.2-15.1)$ & $13.2(10.2-14.5)$ \\
\hline \multicolumn{5}{|c|}{$\begin{array}{l}\text { Wk } 0=\text { week } 0=\text { pre Adacolumn treatment; } W k+2=2 \text { weeks after the last (5th and } 10 \text { th } \\
\text { respectively) Adacolumn treatment. } \\
\text { a All values are given in median and (range). } \\
\text { 'Intravenous iron substitution in } 2 \text { patients during treatment. }\end{array}$} \\
\hline
\end{tabular}

evaluable patients (10/12). After 12 months, 4 patients were evaluable for monitoring. We recorded a mean CAI of 4 (range 0-8) points in these patients. None of them was on steroids at this time (fig. 4). Data of 5 patients are pending. In summary, our observations complied with the observations described in the literature. In patients who responded to GMA, a slight decrease of disease activity and a statistically significant reduction in steroid demand was recorded $(\mathrm{p}=$ 0.001 ). For statistical analysis a post hoc variance analysis for multiple testing was applied.

\section{Conclusion}

The short-term efficacy of GMA in IBD, predominantly in $\mathrm{UC}$, is proven. The treatment appears to be well tolerated, induces short-time remission, and has a drug-sparing effect. Additionally, it can be applied in diseases of other entities which induce similar immunological conditions.

A major drawback of most studies is the short observation period of several weeks to a maximum of 12 months. In 2007 Ljung et al. [57] reported a surveillance of 17 months.

Thus, more randomized, sham-controlled, double-blind trials with a long-term surveillance to evaluate the long-term outcome, treatment schedules, and cost-effectiveness (equipment, pharmacological therapy, avoidance of surgical intervention) are required. Based on the fact that IBD are chronic, relapsing diseases where spontaneous remission rates of up to $40 \%$ per year are not unusual, the implementation of GMA as a routine treatment option in IBD might be reflected thoroughly in view of the missing long-term outcome data.

\section{Guidelines}

American Society for Apheresis (ASFA)

According to current data, the ASFA assigned GMA in IBD to category II with a recommendation level of grade 2B (weak recommendation, moderate quality evidence) [16].

\section{Rationale for Therapeutic Apheresis [16]}

Because of evidence suggesting that granulocytes and monocytes (GM) are pathogenic and the degree of GM infiltration correlates with severity of disease, therapies targeting GM and accompanying inflammatory mediators have been studied. Randomized controlled clinical trials of selective apheresis have demonstrated clinical improvement in IBD patients, including those who are steroid-resistant.

\section{North East Treatment Advisory Group (NETAG)}

In 2011, the NETAG published a guidance for leukopheresis with Adacolumn in IBD including treatment modalities, outcome, safety, and costs [58]

\section{Disclosure Statement}

The authors declared no conflict of interest.

\section{References}

1 Saniabadi AR, Hanai H: Therapeutic apheresis from the early civilizations to the twenty-first cen tury. Gastroenterol Clin Biol 2010;34:645-648.

2 Straube R, Donate H-P, Hager U, Bak K: Vom Aderlass zur Apherese. 2010.

3 Grisham MB, Yamada T: Neutrophils, nitrogen oxides, and inflammatory bowel disease. Ann N Y Acad Sci 1992;664:103-115.

4 Grisham MB, Granger N: Mechanisms of neutrophil-mediated tissue injury; in MacDermott RP, Stenson WF (eds): Inflammatory Bowel Disease. New York, Elsevier, 1992, pp 225-239.

5 Sandborn WJ: Preliminary data on the use of apheresis in inflammatory bowel disease. Inflamm Bowel Dis 2006;12(suppl 1):S15-21.
6 Brannigan AE, O'Connell PR, Hurley H, O'Neill A, Brady HR, Fitzpatrick JM, Watson RW: Neutrophil apoptosis is delayed in patients with inflammatory bowel disease. Shock 2000;13:361-366.

7 Meuret G, Bitzi A, Hammer B: Macrophage turnover in Crohn's disease and ulcerative colitis. Gastroenterology 1978;74:501-503.

8 Papadakis KA, Targan SR: Role of cytokines in the pathogenesis of inflammatory bowel disease. Annu Rev Med 2000;51:289-298.

9 Schreiber S, Nikolaus S, Hampe J, Hamling J, Koop I, Groessner B, Lochs H, Raedler A: Tumour necrosis factor alpha and interleukin 1beta in relapse of Crohn's disease. Lancet 1999;353:459-461.

10 Bicks RO, Groshart KD: The current status of Tlymphocyte apheresis (TLA) treatment of Crohn's disease. J Clin Gastroenterol 1989;11:136-138.
11 Rutgeerts P, Sandborn WJ, Feagan BG, Reinisch W, Olson A, Johanns J, Travers S, Rachmilewitz D, Hanauer SB, Lichtenstein GR, de Villiers WJ Present D, Sands BE, Colombel JF: Infliximab for induction and maintenance therapy for ulcerative colitis. N Engl J Med 2005;353:2462-2476.

12 Stein RB, Hanauer SB: Comparative tolerability of treatments for inflammatory bowel disease. Drug Saf 2000;23:429-448.

13 Toruner M, Loftus EV Jr, Harmsen WS, Zinsmeister AR, Orenstein R, Sandborn WJ, Colombel JF, Egan LJ: Risk factors for opportunistic infections in patients with inflammatory bowel disease. Gastroenterology 2008;134:929-936.

14 Hyde GM, Thillainayagam AV, Jewell DP: Intravenous cyclosporin as rescue therapy in severe ulcerative colitis: time for a reappraisal? Eur J Gastroenterol Hepatol 1998;10:411-413. 
15 Kornbluth A, Marion JF, Salomon P, Janowitz HD: How effective is current medical therapy for severe ulcerative and Crohn's colitis? An analytic review of selected trials. J Clin Gastroenterol 1995; 20:280-284.

16 Szczepiorkowski ZM, Winters JL, Bandarenko N, Kim HC, Linenberger ML, Marques MB, Sarode R, Schwartz J, Weinstein R, Shaz BH: Guidelines on the use of therapeutic apheresis in clinical practice - evidence-based approach from the Apheresis Applications Committee of the American Society for Apheresis. J Clin Apher 2010; 25:83-177.

-17 Sands BE, Sandborn WJ, Feagan B, Lofberg R, Hibi T, Wang T, Gustofson LM, Wong CJ, Vandervoort MK, Hanauer S: A randomized, doubleblind, sham-controlled study of granulocyte/monocyte apheresis for active ulcerative colitis. Gastroenterology 2008;135:400-409.

18 Saniabadi AR, Hanai H, Suzuki Y, Ohmori T, Sawada K, Yoshimura N, Saito Y, Takeda Y, Umemura K, Kondo K, Ikeda Y, Fukunaga K, Nakashima M, Beretta A, Bjarnason I, Lofberg R: Adacolumn for selective leukocytapheresis as a nonpharmacological treatment for patients with disorders of the immune system: an adjunct or an alternative to drug therapy? J Clin Apher 2005;20:171-184.

19 Hanai H: Positions of selective leukocytapheresis in the medical therapy of ulcerative colitis. World J Gastroenterol 2006;12:7568-7577.

20 Hanai H, Iida T, Yamada M, Sato Y, Takeuchi K, Tanaka T, Kondo K, Kikuyama M, Maruyama Y, Iwaoka Y, Nakamura A, Hirayama K, Saniabadi AR, Watanabe F: Effects of Adacolumn selective leukocytapheresis on plasma cytokines during active disease in patients with active ulcerative colitis. World J Gastroenterol 2006;12:3393-3399.

-21 Kashiwagi N, Sugimura K, Koiwai H, Yamamoto H, Yoshikawa T, Saniabadi AR, Adachi M, Shimoyama T: Immunomodulatory effects of granulocyte and monocyte adsorption apheresis as a treatment for patients with ulcerative colitis. Dig Dis Sci 2002; 47:1334-1341.

22 Kuijpers TW, Tool AT, van der Schoot CE, Ginsel LA, Onderwater JJ, Roos D, Verhoeven AJ: Membrane surface antigen expression on neutrophils: a reappraisal of the use of surface markers for neutrophil activation. Blood 1991;78:1105-1111.

-23 Ramlow W, Emmrich J, Ahrenholz P, Sparmann G, Kashiwagi N, Franz M, Yokoyama T, Yoshikawa T: In vitro and in vivo evaluation of Adacolumn cytapheresis in healthy subjects. J Clin Apher 2005;20:72-80.

24 Hanai H, Takeda Y, Eberhardson M, Gruber R, Saniabadi AR, Winqvist O, Lofberg R: The mode of actions of the Adacolumn therapeutic leucocytapheresis in patients with inflammatory bowel disease: a concise review. Clin Exp Immunol 2010; 163: 50-58.

25 Raffler NA, Riviera-Nieves J, Ley K: L-selectin in inflammation, infection and immunity. Drug Discov Today 2005;2:213-220.

26 Waitz G, Petermann S, Liebe S, Emmrich J, Ramlow W: Reduction of dendritic cells by granulocyte and monocyte adsorption apheresis in patients with ulcerative colitis. Dig Dis Sci 2008;53:2507-2515.

27 Cuadrado E: Granulocyte/monocyte apheresis as immunotherapic tool: cellular adsorption and immune modulation. Autoimmun Rev 2009;8: 292-296.

28 Cuadrado E, Alonso M, de Juan MD, Echaniz P, Arenas JI: Regulatory $\mathrm{T}$ cells in patients with inflammatory bowel diseases treated with Adacolumn granulocytapheresis. World J Gastroenterol 2008;14:1521-1527.
29 Biagi E, Di Biaso I, Leoni V, Gaipa G, Rossi V, Bugarin C, Renoldi G, Parma M, Balduzzi A, Perseghin P, Biondi A: Extracorporeal photochemotherapy is accompanied by increasing levels of circulating CD4+CD25+GITR+Foxp3+CD62L+ functional regulatory $\mathrm{T}$-cells in patients with graftversus-host disease. Transplantation 2007:84:31-39.

30 Di Biaso I, Di Maio L, Bugarin C, Gaipa G, Dander E, Balduzzi A, Parma M, D'Amico G, Perseghin P, Biondi A, Biagi E: Regulatory T cells and extracorporeal photochemotherapy: correlation with clinical response and decreased frequency of proinflammatory T cells. Transplantation 2009;87:1422-1425.

31 Beretta A, Clerici M, Hasson H, Fumagalli L, Trabattoni D, Lillo F, Ferrante P, Saniabadi AR, Adachi M, Lazzarin A: Ex-vivo purging of circulating monocytes results in immunovirologic improvement in partially HAART responder HIV-infected patients. J Biol Regul Homeost Agents 2000;14:27-31.

32 Yamamoto T, Umegae S, Matsumoto K: Safety and clinical efficacy of granulocyte and monocyte adsorptive apheresis therapy for ulcerative colitis. World J Gastroenterol 2006;12:520-525.

33 Maruyama Y, Yoshida H, Uchino S, Yokoyama K, Yamamoto H, Takinami M, Hosoya T: Nafamostat mesilate as an anticoagulant during continuous venovenous hemodialysis: a three-year retrospective cohort study. Int J Artif Organs 2011;34:571-576.

34 Hetzel GR, Sucker C: The heparins: all a nephrologist should know. Nephrol Dial Transplant 2005; 20:2036-2042.

35 Takahashi H, Muto S, Nakazawa E, Yanagiba S, Masunaga Y, Miyata Y, Tamba K, Kusano E, Matsuo M, Matsuo T, Asano Y: Combined treatment with nafamostat mesilate and aspirin prevents heparin-induced thrombocytopenia in a hemodialysis patient. Clin Nephrol 2003;59:458-462.

36 Shibata H, Kuriyama T, Yamawaki N: Cellsorba. Ther Apher Dial 2003;7:44-47.

37 Irving PM, Macey MG, Shah U, Webb L, Langmead L, Rampton DS: Formation of platelet-leukocyte aggregates in inflammatory bowel disease. Inflamm Bowel Dis 2004;10:361-372.

38 Passacquale G, Vamadevan P, Pereira L, Hamid C, Corrigall V, Ferro A: Monocyte-platelet interaction induces a pro-inflammatory phenotype in circulating monocytes. PLoS One2011;6:e25595.

39 Calzascia T, Pellegrini M, Lin A, Garza KM, Elford AR, Shahinian A, Ohashi PS, Mak TW: CD4 T cells, lymphopenia, and IL-7 in a multistep pathway to autoimmunity. Proc Natl Acad Sci U S A 2008;105:2999-3004.

40 Schulze-Koops H: Lymphopenia and autoimmune diseases. Arthritis Res Ther 2004;6:178-180.

41 Le Campion A, Gagnerault MC, Auffray C, Becourt C, Poitrasson-Riviere M, Lallemand E, Bienvenu B, Martin B, Lepault F, Lucas B: Lymphopenia-induced spontaneous $\mathrm{T}$-cell proliferation as a cofactor for autoimmune disease development. Blood 2009;114:1784-1793.

42 Danese S, Angelucci E, Stefanelli T, Omodei P, Luigiano C, Finazzi S, Pagano N, Repici A, Vecchi M, Malesci A: Cytapheresis in inflammatory bowel diseases: current evidence and perspectives. Digestion 2008;77:96-107.

43 Triantafillidis JK, Cherakakis P: Current status on the clinical usefulness of apheresis in patients with inflammatory bowel disease. Ann Gastroenterol 2003;16:100-104.

44 Zhu M, Xu X, Nie F, Tong J, Xiao S, Ran Z: The efficacy and safety of selective leukocytapheresis in the treatment of ulcerative colitis: a meta-analysis. Int J Colorectal Dis 2011;26:999-1007.
5 Schoepfer AM, Beglinger C, Straumann A, Trummler M, Renzulli P, Seibold F: Ulcerative colitis: correlation of the Rachmilewitz endoscopic activity index with fecal calprotectin, clinical activity, C-reactive protein, and blood leukocytes. Inflamm Bowel Dis 2009;15:1851-1858.

46 Best WR, Becktel JM, Singleton JW, Kern F Jr: Development of a Crohn's disease activity index. National Cooperative Crohn's Disease Study. Gastroenterology 1976;70:439-444.

47 Tanaka T, Okanobu H, Yoshimi S, Murakami E, Kogame A, Imagawa $\mathrm{H}$, Numata $\mathrm{Y}$, Kuga $\mathrm{Y}$ Moriya T, Ohya T, Kajiyama G: In patients with ulcerative colitis, adsorptive depletion of granulocytes and monocytes impacts mucosal level of neutrophils and clinically is most effective in steroid naive patients. Dig Liver Dis 2008;40:731-736.

48 Yamamoto T, Umegae S, Matsumoto K: Mucosal healing in patients with ulcerative colitis during a course of selective leukocytapheresis therapy: a prospective cohort study. Inflamm Bowel Dis 2010; 16:1905-1911.

49 Habermalz B, Sauerland S: Clinical effectiveness of selective granulocyte, monocyte adsorptive apheresis with the Adacolumn device in ulcerative colitis. Dig Dis Sci 2010;55:1421-1428.

50 Dignass AU, Eriksson A, Kilander A, Pukitis A, Rhodes JM, Vavricka S: Clinical trial: five or ten cycles of granulocyte-monocyte apheresis show equivalent efficacy and safety in ulcerative colitis. Aliment Pharmacol Ther 2010;31:1286-1295.

51 Abreu MT PS, Sands BE, Weinstein R: selektive leukocyte apheresis for the treatment of inflammatory bowel disease. J Clin Gastroenterol 2007;41:874-888.

52 Fujimori J, Yoshino S, Koiwa M, Hirai H, Shiga H, Hayama N, Iino Y: Improvement in rheumatoid arthritis following application of an extracorporeal granulotrap column, G-1. Rheumatol Int 1996;15: 175-180.

53 Nagashima M, Yoshino S, Tanaka H, Yoshida N, Kashiwagi N, Saniabadi AR: Granulocyte and monocyte apheresis suppresses symptoms of rheumatoid arthritis: a pilot study. Rheumatol Int 1998; 18:113-118.

54 Ohara M, Saniabadi AR, Kokuma S, Hirata I, Adachi M, Agishi T, Kasukawa R: Granulocytapheresis in the treatment of patients with rheumatoid arthritis. Artif Organs 1997;21:989-994.

55 Sawada K: Leukocytapheresis as an adjunct to conventional medication for inflammatory bowel disease. Dis Colon Rectum 2003;46(10 suppl):S66-77.

56 Sawada K, Kashiwamura S, Okamura H, Ohnishi K, Fukunaga K, Hirata I, Saniabadi A: Selective granulocyte and monocyte apheresis as a new adjunct to enhance the efficacy of interferon-alpha + ribavirin in patients with high plasma hepatitis $\mathrm{C}$ virus. Dig Liver Dis 2005;37: 515-521.

57 Ljung T, Thomsen OØ, Vatn M, Karlén P, Karlsen LN, Tysk C, Nilsson SU, Kilander A, Gillberg R, Grip O, Lindgren S, Befrits R, Löfberg R: Granulocyte, monocyte/macrophage apheresis for inflammatory bowel disease: the first 100 patients treated in Scandinavia. Scand J Gastroenterol 2007;42:221-227. 58 North East Treatment Advisory Group (NETAG): Leukapheresis with Adacolumn ${ }^{\circledR}$ for Inflammatory Bowel Disease. 2011, pp 1-24. 